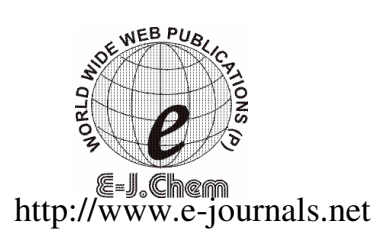

ISSN: 0973-4945; CODEN ECJHAO

E-Journal of Chemistry

2010, 7(S1), S131-S136

\title{
Comparative Study of Leachate Characteristics of Pond Ash from Long-Term Leaching and Ash Pond Disposal Point Effluent from Chandrapura Thermal Power Station, India
}

\author{
RITESH KUMAR \\ Scientist Central Institute of Mining \& Fuel Research (CIMFR) \\ Dhanbad-826015, Jharkhand, India \\ ritesh13@rediffmail.com
}

Received 23 February 2010; Accepted 1 May 2010

\begin{abstract}
The present paper deals with the leaching characteristics of coal combustion residues from chandrapura thermal power station, Jharkhand, India. The study was made under the laboratory as well as the field condition. From the laboratory study conducted so far it is hereby concluded that the leachates of coal combustion residues from chandrapura thermal power station with respect to potentiometric and trace elements analysis are within the permissible limits as per Indian Standards (IS:2490). From the study it is also found that the elements such as arsenic, boron, nickel, etc. could not be detected. The discharge point leachate also does not pose any environmental problem from the point of view of leaching of trace and/or toxic elements as per IS: 2490.
\end{abstract}

Key words: CCRs, Fly ash, Bottom ash, Pond ash, Leachates.

\section{Introduction}

India has proven coal reserves of $240.748 \mathrm{BT}^{1}$. Coal being easily and cheaply available resource it will continue to play the dominant role for decades to come for meeting country's energy requirement. Indian coals are generally characterized as high in ash content. The ash content in the coal varies from 20 percent to 60 percent with an average of 40 percent $^{1-3}$. These high ash coals when used in thermal power plants for power generation huge amount of solid wastes, commonly known as coal combustion residues (CCRs), are generated. Fly ash and bottom ash are commonly referred as CCR. They are generally disposed using wet system of disposal (as practiced in our country by most of the coal based thermal power plants) where they are made into slurry form and pumped to the disposal area especially made for this purpose. The CCR in such disposal pond is known as pond ash. 
Presently, more than 83 coal-based thermal power plants besides other coal based captive power plants that are using this high ash coal for electricity generation. The present CCRs production in the country has crossed 100 MT per annum mark ${ }^{2,-4}$. Such a huge amount of ash is causing great disposal problem and also demanding for some bulk use. Present utilization scene in our country never throws a happy signal, as utilization of ash in our country is still less than 50 percent. This is low as compared to some of the developed countries of the world where the utilization ${ }^{4}$ is as high as $100 \%$.

The major challenge before the nation therefore, is to effectively utilize these CCRs in bulk and that too in an environmentally benign manner. The bulk utilization of the CCRs can be achieved by using it in mine backfilling, mine stowing, filling in the lowlying areas and in the construction industry such as in roads, embankments, dams etc. The first three can be easily taken up but it demands for thorough study of the coal combustion residues with respect to leaching of trace and/or toxic elements. The environmental assessment of CCRs is necessary to know the leaching of trace and/or toxic elements in surface and ground water in its disposal environment to assess its feasibility of bulk utilization.

The present study was undertaken to evaluate the impact of CCRs from chandrapura thermal power station in water environment. For this purpose, long term leaching study was conducted to understand leaching pattern with respect to trace and/or toxic elements. Leachates from discharge point of the ash pond were also regularly monitored and comparison between the two results, the laboratory and the field leaching has been presented in the tabular form in the end.

\section{Study area}

The chandrapura thermal power station of damodar valley corporation is a coal based thermal power station situated in the state of Jharkhand. It is about 45 kilometers to the west of Dhanbad. It is bounded by Damodar River in the south and Pokharia nallah in the east. The power station consists of six units: three units of $130 \mathrm{MW}$ capacity and remaining three units of $120 \mathrm{MW}$ capacities. The total capacity of the power station therefore is $750 \mathrm{MW}$. Coal to the power station is supplied by Dugdha Washery, which is at a distance of three kilometers from the power station.

\section{Experimental}

The environmental assessment of CCRs from chandrapura thermal power station includes:

- Sample collection and preparation

- Open column percolation experiment for long-term leaching analysis.

\section{Sample collection and preparation}

Fly ash, bottom ash and pond ash from chandrapura thermal power station were collected on different days for five consecutive days and a final homogenized sample for each was prepared by mixing appropriate proportions and using coning and quartering methods. The columns of fly ash, bottom ash and pond ash were prepared by placing the respective homogenized samples using standard proctor test. Leachates from discharge point of the ash pond were also regularly collected and stored.

\section{Open column percolation experiment}

Open column percolation experiment was used for leaching study under laboratory condition. The open columns for leaching experiments were made from PVC pipe, 4 inch 
in diameter and $75 \mathrm{~cm}$ in length. CCR samples in the columns were packed at optimum moisture content and density condition. The samples were packed in the columns in such a manner that $15 \mathrm{~cm}$ space was left at the top for water to be ponded over the column ${ }^{5}$.

In this experiment $250 \mathrm{~mL}$ of deionized water was placed every alternate day at the top of the column to maintain sufficient supply of water to the packed material. Leachates were collected every alternate day for six years. This experiment is good for the study of leaching behaviour of the material. This experiment tries to mimic the field situation and also the flow of water through the material occurs in the presence of oxygen at a rate, which depends on the natural permeability of the material.

\section{Apparatus}

The leachates from open column percolation experiment and that from discharge point of ash pond were subjected to potentiometric and elemental analysis. Potentiometric analysis viz. $\mathrm{pH}$, conductivity and TDS were carried out using Cyber Scan $510 \mathrm{pH}$ meter and Cyber Scan 200 conductivity meter respectively. Soon after the potentiometric analysis the leachates were filtered, acidified with $2 \mathrm{~mL}$ of $6 \mathrm{~N} \mathrm{HNO}_{3}$ and stored in the polypropylene beakers in a refrigerator till further analyses with respect to different elements were conducted. Sample analyses were carried out as per the standard procedure recommended by American Public Health Association (APHA, $1985^{6}$ ). Systronic Flame Photometer Model No. 128 was used for the analysis of sodium and potassium. Standard solutions were prepared as the instruction given in the operating manual of the instrument. Atomic absorption spectrophotometer (AAS), GBC-902 coupled with graphite furnace, hydride generator and computer data station was used for the analysis of other elements including trace and/or toxic elements. Standard solutions were prepared as per the instruction given in the operating manual of the GBC-920, $\mathrm{AAS}^{7}$.

\section{Results and Discussion}

Table 1 shows the summarized result of leachate analysis under laboratory condition as per open column percolation experiment and its comparison with Indian Standards ${ }^{8}$ (IS: 2490) for effluent discharge in the Inland Surface Water and On Land for Irrigation. From the study conducted for almost six years it was observed that $\mathrm{pH}$ of all coal combustion residues varied from 6.00 to 9.05 . Thus, the leachates from all coal combustion residues were slightly acidic to alkaline in nature and were within the permissible limits as per IS: 2490.

The conductivity of leachates of fly ash, bottom ash and pond ash varied between 0.209 to $0.973 \mathrm{mmhos} / \mathrm{cm}$ conductivity was found to increase during the initial 30 to 40 days, thereafter it showed decreasing trend till 140 days. It was found to be practically constant after that. Conductivity mainly represents the availability of surfacial elements and this is further related to the particle size. Finer size particles are more leachable than the coarser one. This is the reason why during the initial period of leaching fly ash showed higher value compared to that of bottom ash and pond ash.

Total dissolved solids (TDS) are related to conductivity and it showed similar trend. TDS of fly ash, bottom ash and pond ash varied from 100 to 487 respectively. TDS of all the leachates was within the permissible limit s of IS: 2490. 
Table 1. Leachate analysis (Open Percolation Experiments) of CCRs samples

\begin{tabular}{|c|c|c|c|c|c|c|c|}
\hline \multirow[b]{2}{*}{ Parameters } & \multirow[b]{2}{*}{ FA\#1 } & \multirow[b]{2}{*}{ FA\#2 } & \multirow[b]{2}{*}{ BA\#1 } & \multirow[b]{2}{*}{ BA\#2 } & \multirow[b]{2}{*}{ PA } & \multicolumn{2}{|c|}{ (IS: 2490, 1981) } \\
\hline & & & & & & $\begin{array}{c}\text { Inland } \\
\text { Surface Water }\end{array}$ & $\begin{array}{l}\text { On land for } \\
\text { Irrigation }\end{array}$ \\
\hline $\mathrm{pH}$ & $6.00-8.45$ & $6.20-8.52$ & $6.20-9.05$ & $6.72-8.53$ & $6.56-8.74$ & $5.5-9.0$ & $5.5-9.0$ \\
\hline Conductivity & $0.203-0.962$ & $0.200-0.754$ & $0.290-0.800$ & 0.291-0.794 & $0.372-0.973$ & - & - \\
\hline TDS & $102-481$ & $100-377$ & $145-400$ & $125-397$ & $183-487$ & 2100 & - \\
\hline Iron & BDL-3.85 & BDL-3.12 & BDL-3.12 & BDL-3.12 & BDL-3.12 & - & - \\
\hline Lead & BDL-0.100 & BDL-0.08 & BDL-0.09 & BDL-0.09 & BDL-0.06 & 0.1 & - \\
\hline Magnesium & $11-24$ & $19-34$ & $14-38$ & $10-28$ & $10-20$ & - & - \\
\hline Calcium & $10-25$ & $24-42$ & $26-46$ & $18-40$ & $17-48$ & - & - \\
\hline Copper & BDL-0.09 & BDL-0.09 & BDL-0.2 & BDL-0.06 & BDL-0.05 & 3 & - \\
\hline Zinc & BDL-1.08 & BDL-1.10 & BDL-1.09 & BDL-1.92 & BDL-1.29 & 5 & - \\
\hline Manganese & BDL-0.100 & BDL-0.09 & BDL-0.09 & BDL-0.08 & BDL-0.06 & - & - \\
\hline Sodium & BDL-10 & BDL-16 & BDL-12 & BDL-16 & BDL-10 & - & 60 \\
\hline Potassium & BDL-20 & BDL-36 & BDL-19 & BDL-19 & BDL-18 & - & - \\
\hline Chromium & BDL & BDL & BDL & BDL & BDL & 2 & - \\
\hline Nickel & BDL & BDL & BDL & BDL & BDL & 3 & - \\
\hline Cobalt & BDL & BDL-0.461 & BDL & BDL & BDL-0.473 & - & - \\
\hline Cadmium & BDL & BDL-0.007 & BDL-0.006 & BDL-0.007 & BDL-0.039 & 2 & - \\
\hline Selenium & BDL & BDL & BDL & BDL & BDL & 0.05 & - \\
\hline Aluminium & BDL & BDL & BDL & BDL & BDL & - & - \\
\hline Silver & BDL & BDL & BDL & BDL & BDL & - & - \\
\hline Arsenic & BDL & BDL & BDL & BDL & BDL & 0.2 & 2 \\
\hline Boron & BDL & BDL & BDL & BDL & BDL & 2 & 2 \\
\hline Barium & $\mathrm{BDL}$ & BDL & $\mathrm{BDL}$ & $\mathrm{BDL}$ & BDL & - & - \\
\hline Vanadium & $\mathrm{BDL}$ & $\mathrm{BDL}$ & $\mathrm{BDL}$ & $\mathrm{BDL}$ & $\mathrm{BDL}$ & - & - \\
\hline Antimony & BDL & BDL & BDL & BDL & BDL & - & - \\
\hline Molybdenum & BDL & BDL & BDL & $\mathrm{BDL}$ & BDL & - & - \\
\hline
\end{tabular}

BDL-Below Detectable Limit i.e. $=0.001 \mathrm{mg} / \mathrm{L} ;$ Concentration of Elements in ppm; TDS in ppm; Conductivity in mmhos/cm.

Leachates from five samples of CCRs were analyzed for twenty-two elements. The study showed the absence of elements such as selenium, arsenic, barium, aluminum, boron, nickel, cobalt, cadmium, antimony, silver, molybdenum and chromium. Elements such as calcium, magnesium, sodium, potassium, lead, zinc, iron, copper and manganese were found to be leaching. Calcium and magnesium were observed leaching in the entire study period. This suggests that the coal combustion residues from chandrapura thermal power station are alkaline in nature. Sodium and potassium were observed during the initial period thereafter, it showed intermittent leaching with concentration decreasing considerably in the long run. In case of iron, zinc, copper and lead too intermittent leaching pattern were observed during the study period. In all cases initial high value was observed thereafter, the level showed the decreasing trend and finally reducing to BDL. The comparison of the concentration of leached trace and/or toxic elements with IS: 2490 shows that in case of iron, the value is slightly above the permissible limit on few occasion in the initial study period. However, in most of the cases the leachate concentration was observed within the 
permissible limit as per IS: 2490. In fact, the concentration of all the elements during the study period was observed to be below the permissible limits as per IS: 2490 .

Table 2 shows the summarized result and comparison of leachates from discharge point of ash pond and leachates from column experiment of pond ash. Both the leachates as can be seen from the table shows that values of different parameters are well within the permissible limits as per IS: 2490.

Table 2. Leachate analysis from open percolation experiments of CCRs samples, PA and disposal point effluents (DP)

\begin{tabular}{|c|c|c|c|c|}
\hline \multirow[b]{2}{*}{ Parameters } & \multirow[b]{2}{*}{ PA } & \multirow[b]{2}{*}{ DP } & \multicolumn{2}{|c|}{ (IS: 2490, 1981) } \\
\hline & & & $\begin{array}{c}\text { Inland Surface } \\
\text { Water }\end{array}$ & $\begin{array}{l}\text { On land for } \\
\text { Irrigation }\end{array}$ \\
\hline $\mathrm{pH}$ & $6.56-8.74$ & $7.20-8.58$ & $5.5-9.0$ & $5.5-9.0$ \\
\hline Conductivity & $0.372-0.973$ & $0.482-0.892$ & - & - \\
\hline TDS & $183-487$ & $241-446$ & 2100 & - \\
\hline Iron & BDL-3.12 & BDL-2.941 & - & - \\
\hline Lead & BDL-0.06 & BDL-0.01 & 0.1 & - \\
\hline Magnesium & $10-20$ & $11-19$ & - & - \\
\hline Calcium & $17-48$ & $17-46$ & - & - \\
\hline Copper & BDL-0.05 & BDL-47 & 3 & - \\
\hline Zinc & BDL-1.29 & $0.61-1.015$ & 5 & - \\
\hline Manganese & BDL-0.06 & BDL & - & - \\
\hline Sodium & BDL-10 & BDL-10 & - & 60 \\
\hline Potassium & BDL-18 & BDL-18 & - & - \\
\hline Chromium & BDL & BDL & 2 & - \\
\hline Nickel & $\mathrm{BDL}$ & BDL & 3 & - \\
\hline Cobalt & BDL-0.473 & BDL & - & - \\
\hline Cadmium & BDL-0.039 & BDL & 2 & - \\
\hline Selenium & BDL & BDL & 0.05 & - \\
\hline Aluminium & BDL & BDL & - & - \\
\hline Silver & BDL & BDL & - & - \\
\hline Arsenic & BDL & BDL & 0.2 & 2 \\
\hline Boron & BDL & BDL & 2 & 2 \\
\hline Barium & BDL & BDL & - & - \\
\hline Vanadium & BDL & BDL & - & - \\
\hline Antimony & $\mathrm{BDL}$ & BDL & - & - \\
\hline Molybdenum & BDL & BDL & - & - \\
\hline Mercury & $\mathrm{BDL}$ & BDL & 0.01 & - \\
\hline
\end{tabular}

BDL-Below Detectable Limit; Concentration in ppm; TDS in ppm; Conductivity in mmhos/cm.

\section{Conclusion}

From the study so conducted it can be concluded that the leachates as such do not show any negative effects on the water environment either surface water or the ground water. However, 
from the point of view of safety one can go for treatment of the leachates being released in the water environment at the discharge point of the ash pond in case of the discharge point effluent.

\section{Acknowledgment}

The authors thank the concerned authorities of the Indian School of Mines and Central Institute of Mining \& Fuel Research, Dhanbad for providing facilities to carry out this work.

\section{References}

1. TEDDY (Teri Energy Data Directory \& Yearbook), Annual Report, 2009.

2. Ashokan P, Saxena M and Asholekar S R, Resources, Conservation and Recycling, 2005, 43(3), 239-262.

3. Chandra N, Sharma P, Pashkov G L, Voskresenskaya E N, Amritphale S S and Baghel N S, Waste Management, 2008, 28(10), 1993-2002.

4. Ram L C, Srivastava N K, Tripathi R C, Thakur S K, Sinha A K, Jha S K, Masto R E and Mitra S, Environmental Geology, 2007, 51(7), 1119-1132.

5. Singh G and Kumar S, Indian J Environ Protect., 1998, 18(12), 884-888.

6. APHA, Standard Methods for the Examination of Water and Wastewater, American Public Health Association, Washington, 1989.

7. Atomic Absorption Spectrophotometer Operating Manual, AAS, GBC-902, Australia, 1990.

8. ISI, Indian Standard Specification for Effluent Discharge in Surface Water and On Land for Irrigation, IS: 2490 (Part I), ISI, New Delhi, 1983. 


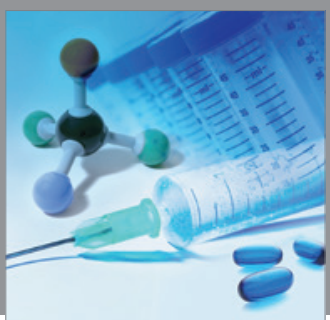

International Journal of

Medicinal Chemistry

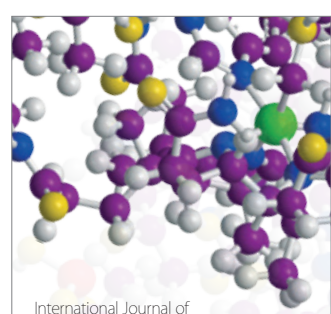

Carbohydrate Chemistry

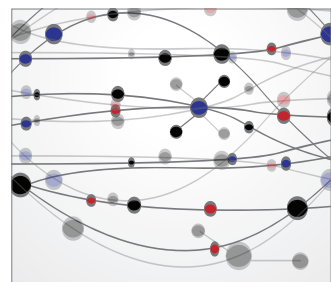

The Scientific World Journal
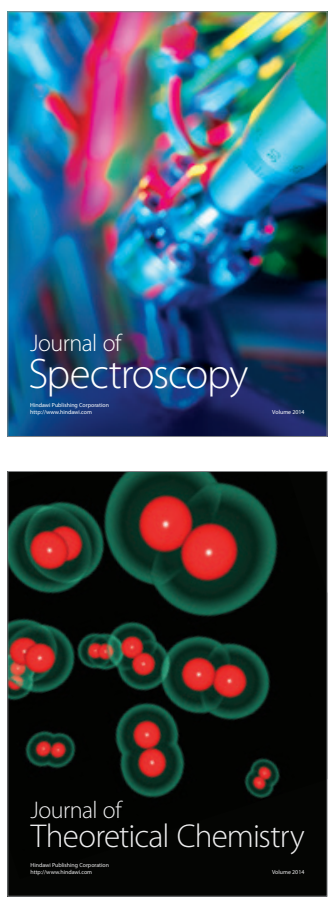
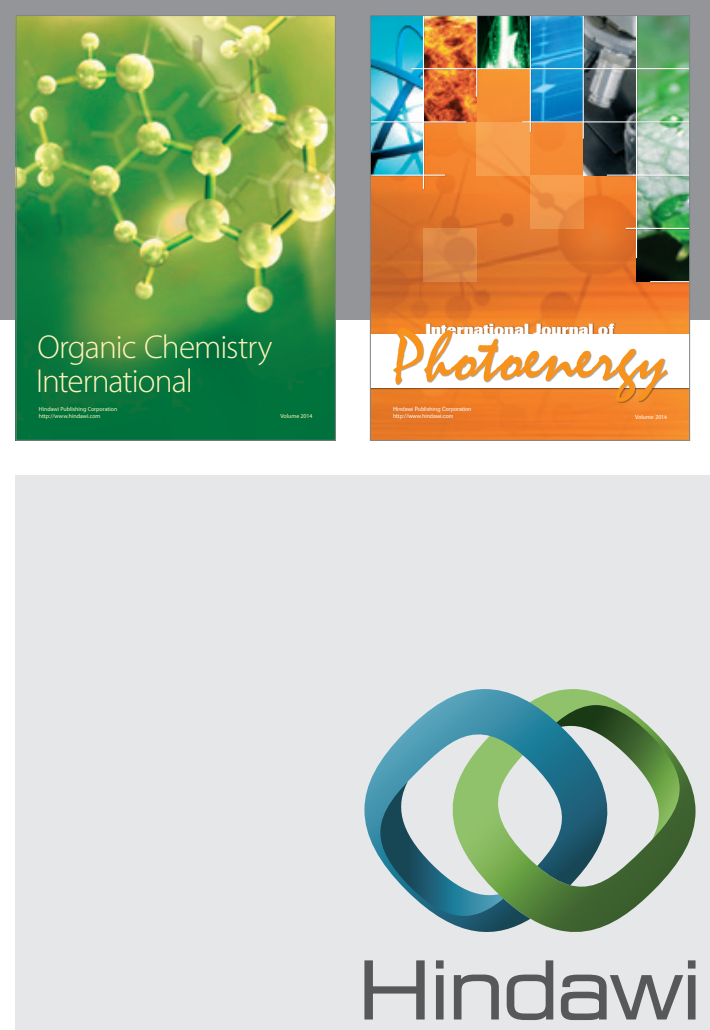

Submit your manuscripts at

http://www.hindawi.com
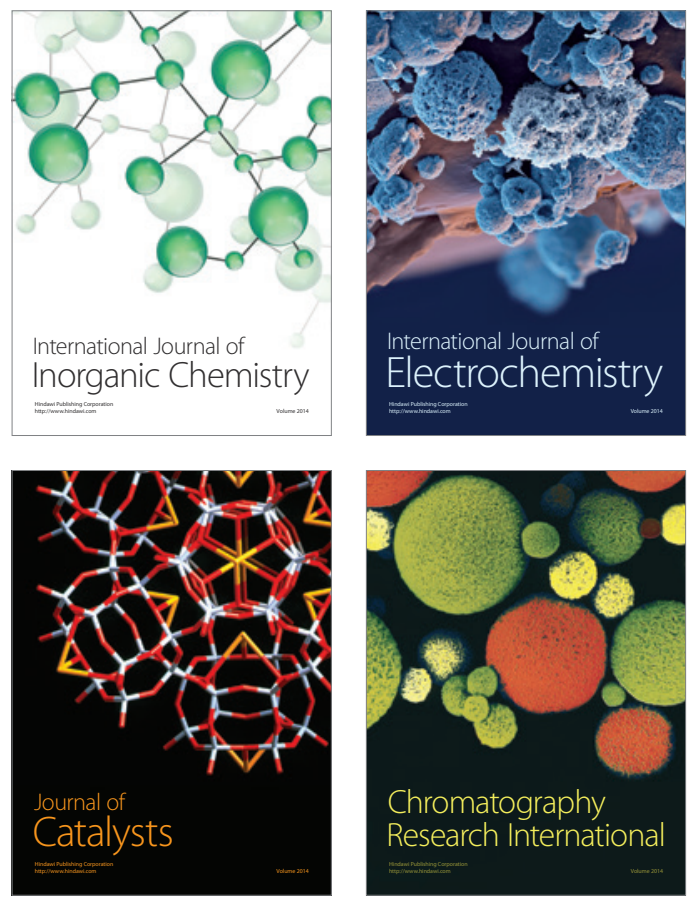
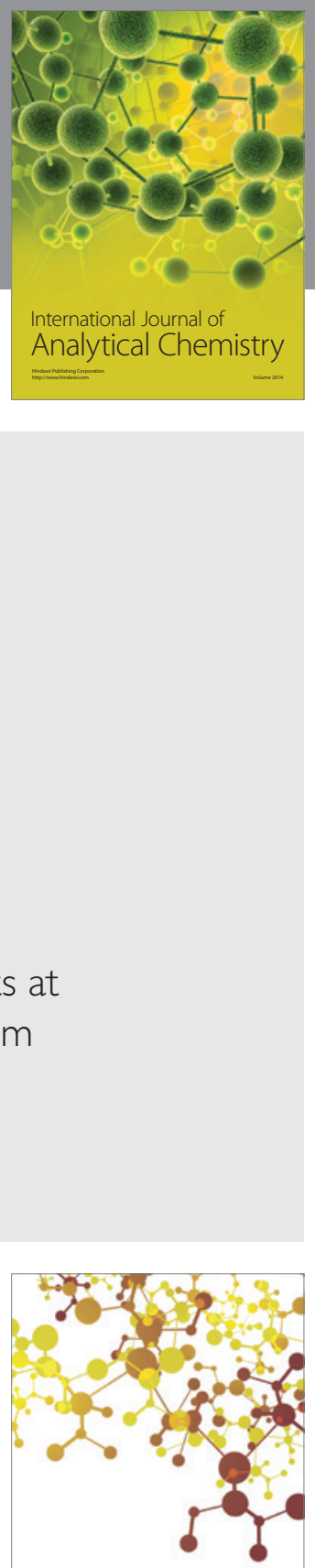

Journal of

Applied Chemistry
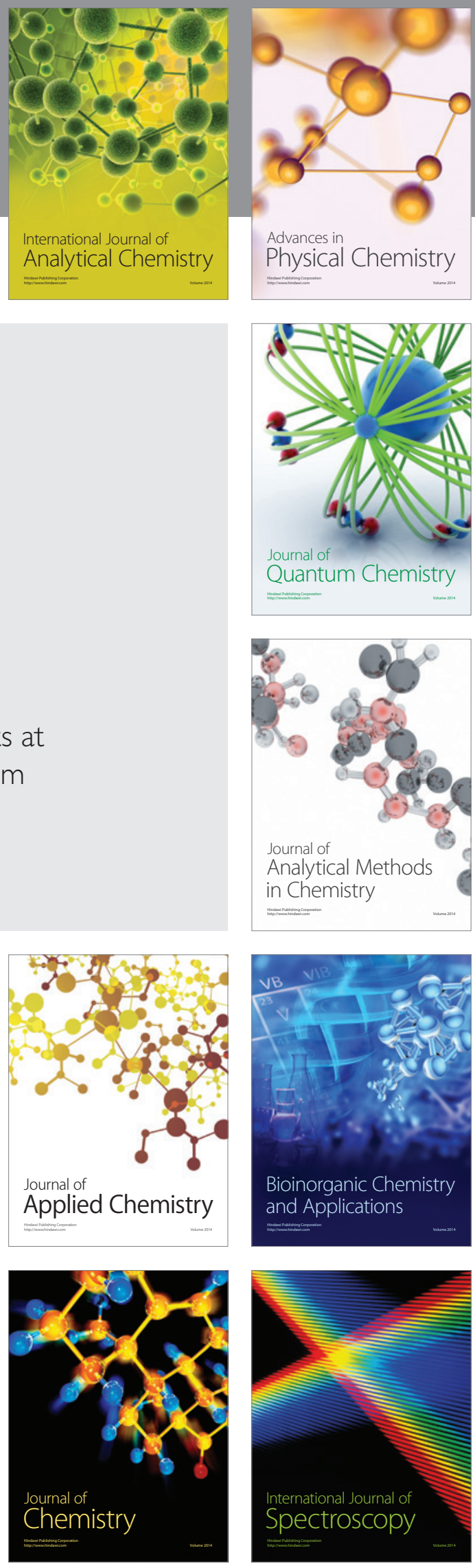